\title{
ULTRASTRUCTURE OF TWO TYPES OF ENDOCRINE CELLS IN THE MIDGUT EPITHELIUM OF SPODOPTERA EXIQUA HÜBNER, 1808 (INSECTA, LEPIDOPTERA, NOCTUIDAE)
}

\author{
Magdalena M. Rost-Roszkowska*, Agata Chechelska, \\ MACIEJ FRĄDCZAK and KATARZYNA SALITRA
}

University of Silesia, Department of Animal Histology and Embryology, Bankowa 9, 40-007 Katowice, Poland

* corresponding author: mrost@us.edu.pl

\begin{abstract}
Midgut epithelium of Lepidoptera consists of four types of cells: columnar, goblet, endocrine and regenerative. Among endocrine cells two types have been distinguished: "open" and "closed". In all five larval instars of Spodoptera exiqua (Lepidoptera, Noctuidae) only "open" endocrine cells were observed, which means that their apical membranes contact with the midgut lumen and form microvilli like columnar cells of epithelial character. Among them granular and vesicular cells are distinguishable. The number of vesicular endocrine cells increases distinctly in the $5^{\text {th }}$ larval instar. The structure of endocrine cells in the midgut epithelium of $S$. exiqua and their differentiation from the regenerative cells, studied in transmission electron microscope, are described.
\end{abstract}

Key words: endocrine cells, midgut epithelium, granular cells, vesicular cells, Lepidoptera

\section{INTRODUCTION}

Lepidopteran midgut is composed of four types of cells: columnar, goblet, endocrine and regenerative (ANDriÉs and TrAmu, 1985; LEHANE and BillingSLey, 1996; Pinheiro et al., 2003; Levy et al., 2004). Endocrine cells have been observed between epithelial cells in the midgut epithelium of the majority of 
insects, but they have been described mainly for Lepidoptera, Ephemeroptera, Trichoptera and Plecoptera (Montuenga et al., 1989; Nishitsutsuji-Uwo and Endo, 1981; Rost-Roszkowska, 2008). They are responsible for the regulation of enzyme synthesis and secretion (Montuenga et al., 1989; Chapman, 1998). In some insect species only one type of endocrine cells has been found while in others several different types have been detected (Montuenga et al., 1989; Neves et al., 2002, 2003). They are described as oval, pyramid or bowl-shaped cells (Andriés and Beauvillain, 1988; Cavalcante and Cruz-Landim, 1999), and originate from the regenerative cells. In recent years the structure of endocrine cells has been described. They differ structurally from the other epithelium cells (Endo and Nishiitsutsuji-Uwo, 1981; Gül et al., 2001; Levy et al., 2004). The presence of somatostatin, pancreatic polypeptide and FMRFamide-related peptides has also been analyzed in the cytoplasm of endocrine cells (ENDO et al., 1982; Andriés and Tramu, 1985; Zudaire et al., 1998). Their activity is associated with the presence of a great number of electron dense secretory granules, which are mainly accumulated in their basal cytoplasm (RAES and VerBeKE, 1994; Billingsley and Lehane, 1996; Levy et al., 2004).

The aim of our studies was to analyse the ultrastructure of endocrine cells in relation to their endocrine activity in the midgut epithelium of all larval instars of Spodoptera exiqua (Insecta, Lepidoptera), a species of great ecnomic importance.

\section{MATERIAL AND METHODS}

The material for the study originated from the laboratory culture of $S$. exiqua. Larvae $\left(1^{\text {st }}-5^{\text {th }}\right)$ and isolated midgut were fixed with $2.5 \%$ glutaraldehyde in $0.1 \mathrm{M}$ phosphate buffer at $\mathrm{pH} 7.4\left(4^{\circ} \mathrm{C}, 2 \mathrm{~h}\right)$ and postfixed with $2 \% \mathrm{OsO}_{4}\left(4^{\circ} \mathrm{C}\right.$, $1.5 \mathrm{~h})$. After dehydration in a graded series of alcohols $(50 \%, 70 \%, 90 \%, 96 \%$,

Fig. 1. Midgut epithelium in all larval stages of Spodoptera exiqua is formed by columnar (c), endocrine (e), goblet (g) and regenerative (arrow) cells. Midgut lumen (1). Light microscope, bar $=80 \mu \mathrm{m}$.

Fig. 2. $1^{\text {st }}$ larval instar of $S$. exiqua. Endocrine cells (e), regenerative cells (r), columnar cell (c), basal lamina (arrow). TEM, bar $=24 \mu \mathrm{m}$.

Fig. 3. $3^{\text {rd }}$ larval instar of $S$. exiqua. Regenerative cell (r), endocrine cell (e), goblet cell (g), basal lamina (arrow), nucleus of the regenerative cell (n). TEM, bar $=20 \mu \mathrm{m}$.

Fig. 4. $2^{\text {nd }}$ larval instar of S. exiqua. Columnar cell (c), "open” endocrine cell (e), microvilli (mv), granular material (probably glycogen) in the cytoplasm of endocrine cell (arrow). TEM, bar $=37 \mu \mathrm{m}$.

Fig. 5. $4^{\text {th }}$ larval instar of $S$. exiqua. Granular endocrine cell. Asterisks indicate accumulation of granular material (glycogen). TEM, bar $=7 \mu \mathrm{m}$. 
I
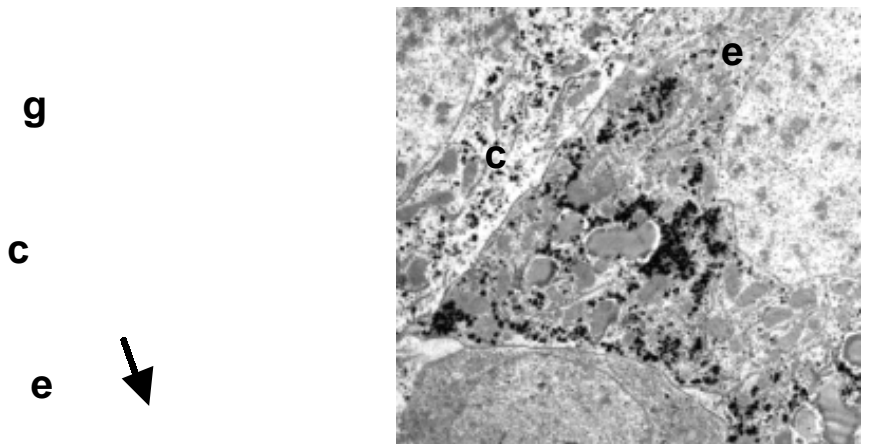

(1)
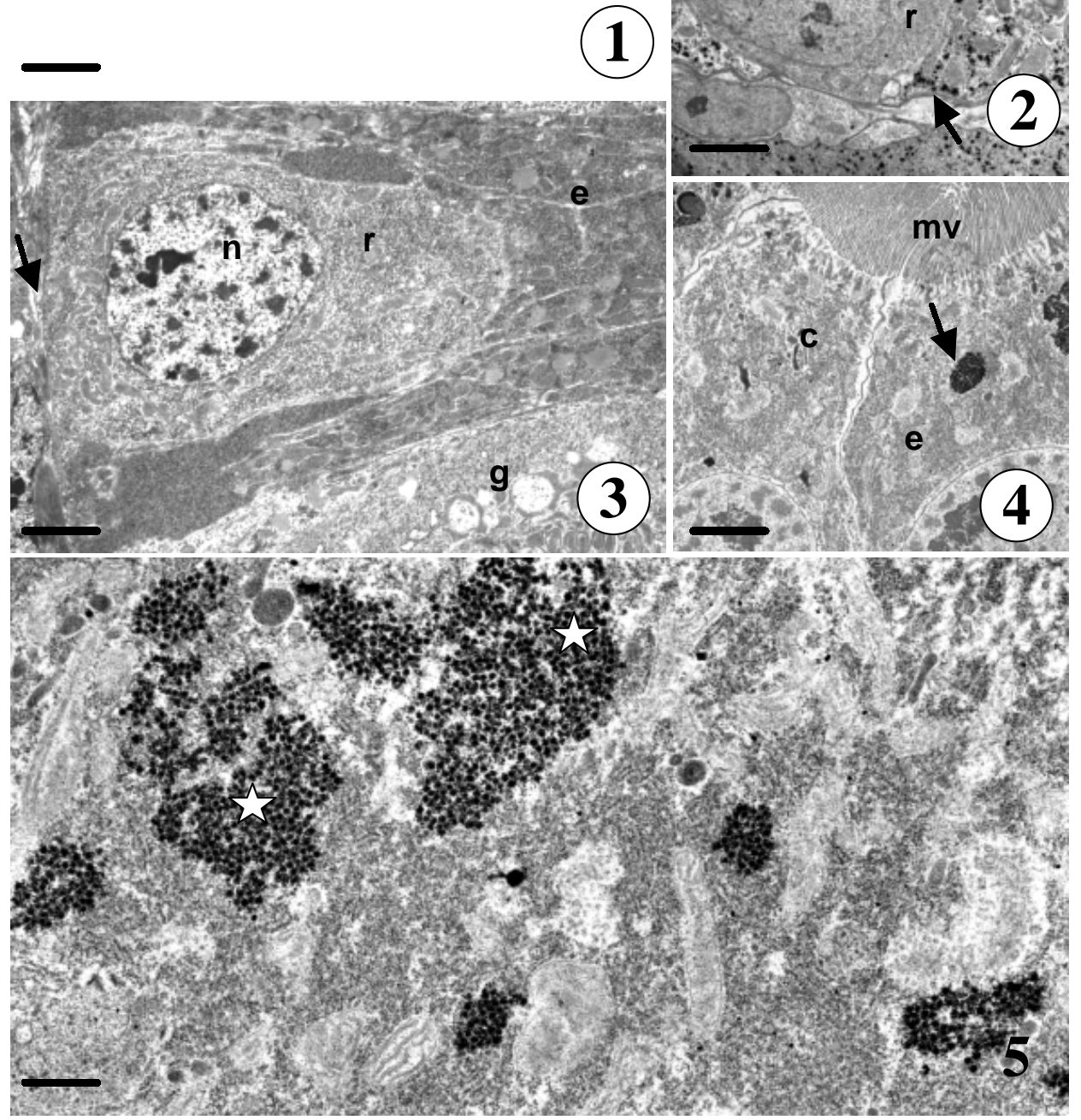
and $100 \%$ for 15 minutes each) and acetone ( $15 \mathrm{~min})$, the material was embedded in Epon 812. Semithin sections, after cutting with the Leica Ultracut UCT25 ultramicrotome, were stained with $1 \%$ methylene blue in $0.5 \%$ borax and examined in an OLYMPUS BX60 light microscope. Ultrathin sections were cut with the Leica Ultracut UCT25 ultramicrotome and stained with uranyl acetate and lead citrate. They were examined with a Hitachi H500 transmission electron microscope at $75 \mathrm{kV}$.

\section{RESULTS}

Midgut epithelium of $S$. exiqua is formed by columnar, goblet, endocrine and regenerative cells (Fig. 1). The endocrine cells are singly distributed among columnar cells and they localize in the neighborhood of regenerative cells (Fig. 2). At the beginning of each larval instar $\left(1^{\text {st }}-5^{\text {th }}\right)$ it is difficult to distinguish the columnar cells of endocrine character. Regenerative cells are able to proliferate and differentiate into columnar, endocrine and goblet cells (Fig. 3). It is easy to detect the differentiation of goblet or columnar cells, but columnar cells achieve an endocrine character just after reaching the midgut lumen. The regenerative cell first elongates towards the midgut lumen. After microvilli formation and reaching the midgut lumen, it differentiates into columnar or endocrine type. Thus the endocrine cells of the midgut epithelium in S. exiqua are of the "open" type, which means that their apical membranes, which form microvilli, contact with the midgut lumen (Fig. 4).

The basal membranes of endocrine cells do not form visible folds. In their cytoplasm numerous Golgi complexes, cisterns of SER and RER and lamellar structures occur (Fig. 5). In the $1^{\text {st }}$ to $5^{\text {th }}$ larval instars two types of "open" endocrine cells were observed: granular and vesicular. The granular endocrine cells have accumulations of electron dense granules which are probably glycogen granules. They are initially accumulated in the basal cytoplasm (Fig. 6). Afterwards, the granules occur also in the perinuclear and apical cytoplasm (Figs. 5, 7). The vesicular endocrine cells are rich in small and large electron lucent vacuoles with visible electron dense core inside. They are present in the entire cytoplasm (Figs. 8,9). In the $5^{\text {th }}$ larval instar we observed that the number of vesicular endocrine cells increased in comparison with larval instars $1^{\text {st }}-4^{\text {th }}$.

\section{DISCUSSION}

Two major kinds of endocrine cells have been distinguished in the insect midgut epithelium: "open" and "closed" endocrine cells. The apical membrane of the "open" endocrine cells, forming numerous microvilli, contacts the midgut lumen (Reinhardt, 1976; Glättli et al., 1987), whereas the endocrine cells of the "closed" type do not reach the midgut lumen and their apical membranes do not form microvilli (Andriés, 1976; Billingsley and Downe, 1986; Serrăo and Cruz- 


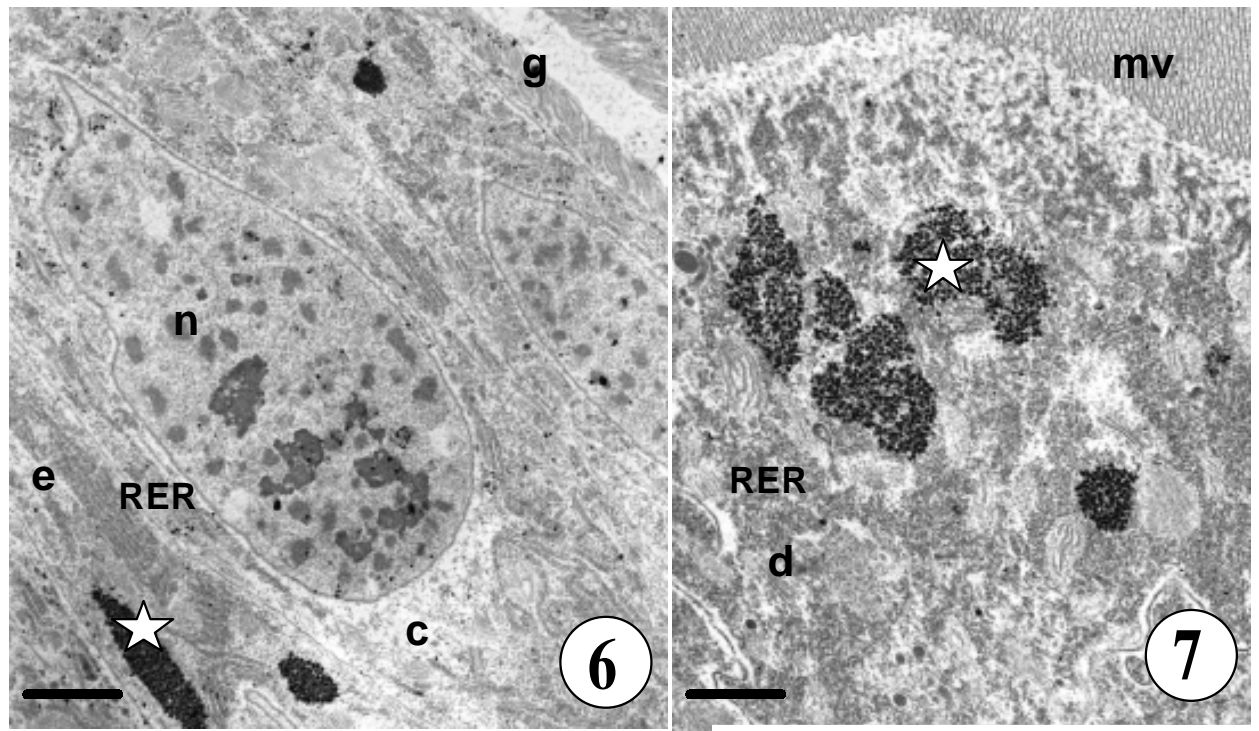

$\mathbf{v}$

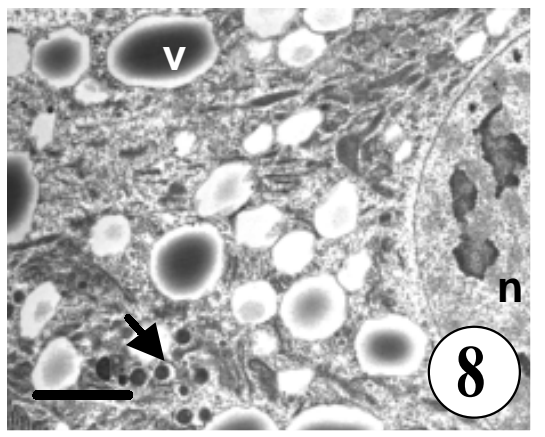

e

$\mathbf{n}$

g

e

Fig. 6. $4^{\text {th }}$ larval instar of $S$. exiqua. Part of the midgut epithelium. Endocrine cell (e), goblet cell (g), columnar cell (c), nucleus of the columnar cell (n), granular material (asterisk). TEM, bar $=23 \mu \mathrm{m}$.

Fig. 7. $4^{\text {th }}$ larval instar of $S$. exiqua. Apical region of the endocrine cell. Microvilli (mv). Rough endoplasmic reticulum (RER), Golgi complexes (d), granular material (asterisk). TEM, bar $=12 \mu \mathrm{m}$.

Fig. 8. Vesicular endocrine cell in the midgut epithelium of the $2^{\text {nd }}$ instar larva of $S$. exiqua. Vesicles (v), lamellar structures (arrow), nucleus of endocrine cell (n). TEM, bar $=19 \mu \mathrm{m}$. Fig. 9. Part of the midgut epithelium of the $5^{\text {th }}$ instar larva of $S$. exiqua. Vesicular endocrine cells (e), goblet cells (g), vesicles (v), nucleus of endocrine cell (n). TEM, bar $=23 \mu \mathrm{m}$. 
LANDIM, 1996). Among those two types of endocrine cells several different kinds have been described (Andriés and Beauvillain, 1988; Raes and Verbeke, 1994; Cavalcante and Cruz-Landim, 1999; Gül et al., 2001; Neves et al., 2003). In $S$. exiqua only the "open" type of endocrine cells was observed. They have microvilli, which contact the midgut lumen. In some insect species among the „open” endocrine cells of the posterior midgut two kinds of cells have been distinguished (Neves et al., 2002, 2003). The cytoplasm of one type contains great numbers of electron dense granules, which are called granular cells, while the other kind has numerous vacuoles with electron lucent contents (RAES and Verbeke, 1994; GüL et al., 2001). The endocrine cells of some insect species have been observed to contain electron dense homogenous granules and structures with distinct electron dense core (LEVy et al., 2004). In Schistocerca gregaria 10 types of endocrine cells have been described: 7 types present in both the anterior and posterior midgut, and 3 types in the neighborhood of Malpighian tubules openings (Montuenga et al., 1989). The character of material accumulated in the cytoplasm of endocrine cells and the number of endocrine cell types are probably associated with the peptides which are produced in their cytoplasm (Neves et al., 2002, 2003). In S. exiqua two kinds of open cells were observed: granular and vesicular. However, in the $5^{\text {th }}$ larval instar the number of vesicular endocrine cells increases, which might be connected with the additional peptides produced and secreted just before pupal stage.

Lepidopteran endocrine cells have electron lucent cytoplasm with numerous Golgi complexes and vacuoles. Their basal membranes do not form any folds. In some insect species glycogen granules have been detected (ENDO and Nishitssutsuji-Uwo, 1981; Nishitsutsuji-Uwo and Endo, 1981; Montuenga et al., 1989; Billingsley, 1990; Levy et al., 2004; Neves et al., 2003). Secretory vacuoles and granules are mainly accumulated in the basal cytoplasm (RAES and Verbeke, 1994; Billingsley and Lehane, 1996; Cristofoletti et al., 2001; Levy et al., 2004). The structure of endocrine cells in the studied species is similar to that described for many insect species, granular structures are observed in the entire cytoplasm.

The endocrine cells in the insect midgut epithelium are thought to be functionally similar to neurosecretory cells of the vertebrate alimentary tract (Billingsley and Lehane, 1996; Levy et al., 2004). They synthesize polypeptide hormones (Endo et al., 1982; Andriés and Tramu, 1985; Zudaire et al., 1998), which are responsible for proper and specific enzyme secretion and control proliferation and differentiation of the regenerative cells. The 5th larval instar of $S$. exiqua is the last one before pupal stage, and the organism must be prepared for many changes associated with pupation: the secretory functions of the endocrine cells are probably intensified and new hormones synthesized. 


\section{ACKNOWLEDGEMENTS}

We would like to express our gratitude to Professor J. Klag for critical reading of the manuscript. Thanks are also due to Dr. D. Urbańska-Jasik (Department of Animal Histology and Embryology, University of Silesia) for her professional technical assistance, and Dr. A. Kafel (Department of Animal Physiology and Ecotoxicology, University of Silesia) for collecting the material.

\section{ULTRASTRUKTURA DWÓCH TYPÓW KOMÓREK ENDOKRYNOWYCH W NABŁONKU JELITA ŚRODKOWEGO SPODOPTERA EXIQUA HÜBNER, 1808 (INSECTA, LEPIDOPTERA, NOCTUIDAE)}

\section{STRESZCZENIE}

Nabłonek jelita środkowego owadów należących do Lepidoptera tworzony jest przez cztery typy komórek: trawienne, kubkowe (kielichowate), endokrynowe oraz regeneracyjne. Wśród komórek endokrynowych rozróżniamy dwa ich rodzaje: otwarte oraz zamknięte.

We wszystkich pięciu stadiach larwalnych Spodoptera exiqua (Lepidoptera, Noctuidae) były obserwowane jedynie komórki endokrynowe typu otwartego, których błony apikalne kontaktując się ze światłem jelita tworzą mikrokosmki, podobnie jak komórki trawienne. Wśród nich można wyróżnić zarówno komórki ziarniste zawierające liczne elektronowo gęste granule, a także komórki pęcherzykowate z licznymi elektronowo jasnymi wakuolami. Liczba komórek endokrynowych o charakterze pęcherzykowatym zdecydowanie wzrasta w ostatnim piątym stadium larwalnym badanego gatunku. Struktura komórek endokrynowych, a także proces ich różnicowania z komórek regeneracyjnych został opisany z wykorzystaniem transmisyjnej mikroskopii elektronowej.

\section{REFERENCES}

Andriés, J.C., 1976: Presence de deux type cellulaires endocrines et d'un type exocrine au sein du mesenteron de la larve d'Aeshna cyanea Müller (Odonata: Aeshnidae). Int. J. Insect Morphol. Embryol., 5: 393-407.

Andriés, J.C., Tramu, G., 1985: Ultrastructural and immunohistochemical study of endocrine cells in the midgut of the cockroach Blaberus craniifer (Insecta, Dictyoptera). Cell Tissue Res., 240: 323-332.

Andriés, J.C., Beauvillain J.C., 1988: Ultrastructural study of cholecystokininlike immunoreactivity in endocrine cells of the insect midgut of Nepa cinerea (Insecta, Heteroptera): ultrastructure and genesis. Biol. Cell., 46: 195-202. 
Billingsley, P.F., 1990: The midgut ultrastructure of hematophagous insects. Annu. Rev. Entomol., 35: 219-248.

Billingsley, P.F., Downe, A.E.R.,1986: Nondigestive cell types in the midgut epithelium of Rhodnius prolixus (Hemiptera, Reduviidae). J. Med. Entomol., 23: 212-216.

Billingsley, P.F., Lehane, M.J., 1996: Structure and ultrastructure of the insect midgut, In: M. J. Lehane \& P. F. Billingsley (eds.), Biology of the insect midgut. Chapman \& Hall, London, pp. 3-30.

Cavalcante, V.M., Cruz-Landim, C., 1999: Types of cells present in the midgut of the insects: a review. Naturalia, 24: 19-40.

Chapman, R.F., 1998: The Insects: Structure and Function. $4^{\text {th }}$ edition. Cambridge University Press, pp. 38-66.

Cristofoletti, P.T., Ribeiro, A.F., Terra, W.R., 2001: Apocrine secretion of amylase and exocytosis of trypsin along the midgut of Tenebrio molitor larvae. J. Insect Physiol., 47: 143-155.

Endo, Y., Nishitsutsuji-Uwo, J., 1981: Gut endocrine cells in insects: the ultrastructure of the gut endocrine cells of the lepidopterous species. Biomed. Res., 2: 270-280.

Endo, Y., Nishitsutsuji-Uwo, J., Iwanaga, T. Fujita, T., 1982: Ultrastructural and immunohistochemical identification of pancreatic polypeptide-immunoreactive endocrine cells in the cockroach midgut. Biomed. Res., 3(4): 454-456.

Glättli, E., Rudin, W., Hecker, H.,1987: Immunoelectron microscopic demonstration of pancreatic polypeptide in midgut epithelium of hematophagous dipterans. J. Histochem. Cytochem., 35: 891-896.

Gül, N., Sayar, H., Özsoy, N., Ayvali, C., 2001: A study on endocrine cells in the midgut of Agrotis segetum (Denn.and Schiff.) (Lepidoptera: Noctuidae). Turk. J. Zool., 25: 193-197.

Lehane, M.J., Billingsley, P.F., 1996: Biology of the insect midgut. London, Chapman and Hall, 486p.

Levy, S.M., Falleiros, A.M.F., Gregório, E.A., Arrebola, N.R., Toledo, L.A., 2004: The larval midgut of Anticarsia gemmatalis (Hübner) (Lepidoptera: Noctuidae): light and electron microscopy studies of the epithelial cells. Braz. J. Biol., 64: 633-638.

Montuenga, L.M, Barrenechea, M.A., Sesma, P., Lopez, J., Vazquez, J.J., 1989: U1trastructure and immunocytochemistry of endocrine cells in the midgut of the desert locust, Schistocerca gregaria (Forskal). Cell Tissue Res., 258: 577-583.

Neves, C.A., Bhering, L.L, Serrăo, J.E., Gitirana, L.B., 2002: FMrFamide-like midgut endocrine cells during the metamorphosis in Melipona quadrifasciata anthidioides (Hymenoptera, Apidae). Micron, 33: 453-460.

Neves, C.A., Gitirana, L.B., Serrăo, J.E., 2003: Ultrastructure of the midgut endocrine cells in Melipona quadrifasciata anthidioides (Hymenoptera, Apidae). Braz. J. Biol., 63: 683-690.

Nishitsutsuji-Uwo, J., Endo, Y., 1981: Gut endocrine cells in insects: the ultrastructure of the endocrine cells in the cockroach midgut. Biomed. Res., 2(1): 30-44.

Pinheiro, D.O., Silva, R.J., Quagio-Grassiotto, I., Gregório, E.A., 2003: Morphometric study of the midgut epithelium in larvae of Diatraea saccharalis Fabricius (Lepidoptera: Pyralidae). Neotrop. Entomol., 32(3): 453-459 
Raes, H., Verbeke, M., 1994: Light and electron microscopical study of two types of endocrine cells in the midgut of the adult worker honeybee (Apis mellifera). Tissue Cell, 26: 223-230.

Reinhardt, C.H., 1976: Ultrastructural comparison of the midgut epithelia of fleas with different feeding behavior patterns (Xenopsylla cheopis, Echidnophaga gallinacea, Tunga penetrans, Siphonaptera, Pulicidae). Acta Trop., 3: 105-132.

Rost-Roszkowska, M.M., 2008: Ultrastructural changes in the midgut epithelium of Acheta domesticus L. (Insecta, Orthoptera, Gryllidae) during degeneration and regeneration. Ann. Entomol. Soc. Am., 101: 151-158.

Serrăo, J.E., Cruz-Landim, C., 1996: Ultrastructure of midgut endocrine cells in workers of stingless bee (Hymenoptera, Apidae, Meliponinae). Iheringia Ser. Zool., Porto Alegre, 81: 151-156.

Zudaire, E., Simpson, S.J., Montuenga, L.M., 1998: Effects of food nutrient content, insect age and stage in the feeding cycle on the FMRFamide immunoreactivity of diffuse endocrine cells in the locust gut. J. Exp. Biol., 201: 2971-2979.

Received 2008-04-07 